\title{
Determining the Effect of Modeling Discipline Management Approach on English Language Reading Readiness of Children in Class One at Kericho Rehabilitation School, Kenya
}

\author{
Jaluo Murunga William Prof Gatumu C, Jane Dr Origa O. Japheth \\ School of Education, University of Nairobi, P.O. Box 30197,GPO, Nairobi, Kenya
}

\begin{abstract}
English Language Reading Readiness (ELRR) is preparation of children by giving them the chance to improve the ability to listen, and speak effectively, to apply the desired vocabulary, and develop the appropriate academic readiness skills. English Language Reading Readiness is of great importance in improving equity in access to learning language and education results, particularly for juvenile delinquency. Children in rehabilitation schools have a vital social issue that every Nation tries to contain its control amongst the clear evidence, with the correct nurturing such as psychotherapeutic interventions is not provided to the young offenders, they may eventually graduate to hardcore criminals. Modelling or modeling is a method used in certain techniques of psychotherapy whereby the client learns by imitation alone, without any specific verbal direction by the therapist and a general process in which persons serve as models for others, exhibiting the behaviour to be imitated by the others. This process is most commonly discussed with respect to children in developmental psychology. The objective of the study was to determine the effect of modeling discipline management method on English Language Reading Readiness of children in class one at Kericho Rehabilitation School. The study also utilized the hypothesis which stated that there is no significant difference between the mean score of the group of children taught without using the modeling discipline management method and the mean score of the group taught using the modeling discipline management method in English Language Reading Readiness of children in class one at Kericho Rehabilitation School. However, little research has been done on the effect of modeling discipline management method on English Language reading readiness in rehabilitation schools setting. The study adopted a case study research design that utilized a quasi-experimental design. The target population included 1 Head teacher, 3 teachers and 25 learners in class 1 at the Kericho Rehabilitation School. Data collection was done using a combination of an English Language Reading Readiness Test, a questionnaire, document analysis and observation. The data was analyzed both descriptively and inferentially. The findings revealed that the null hypothesis was rejected and adopt the alternative hypothesis. The results show and it is recommended that the children's performance in English Language Reading Readiness can be improved when the teachers use modeling discipline management method in rehabilitation schools.
\end{abstract}

Keywords: Kenya, Kericho Rehabilitation School, Modeling, Discipline, Management, Case study

DOI: $10.7176 / \mathrm{JEP} / 10-25-07$

Publication date:September $30^{\text {th }} 2019$

\section{Introduction}

Reading is an extraordinary thing. It is one of the most important skills acquired in early childhood. And while it's distinctly unnatural, it forms an intrinsic part of our lives. According to Burchinal, Roberts, Hooper and Zeisel (2000), best-trained and supportive teachers, who apply reasonable degree of praise, proactive teaching strategies, and non-harsh discipline; can play an extremely significant role in fostering the social and emotional skills development and preventing the conduct problems in young children together with enhancing language readiness among children. Modelling is an important component of classroom discipline programming, which field has further developed specialized techniques involving modeling.

Kericho Rehabilitation School is one of the ten Children's Correction and Rehabilitation Centres in Kenya that are run by the Department of Children's Services. The Department also runs twelve Children's Remand Homes as well as three Children's Rescue Centres. These institutions have various rehabilitation programmes, carried over from the colonial administration, including education service to Kenyan juvenile children, aged $10-12$ years who are found to be in conflict with the law.

\section{Statement of the Problem}

Kericho Rehabilitation School, Kenya caters for the rehabilitation of boy-children between the ages of 10 - 12, but the overall effect of these programmes is rather weak because the mechanisms in place often lean more towards behavior adjustment rather than address the existing English language Reading Readiness in learning situations (Kinyua, 2014). A survey conducted by Uwezo Kenya (2009-2013) on monitoring learner achievement indicates that for the first three years, the state of literacy skills in Kenya is grim. It exposed that actually nationally; only 3 out of 10 children in class 3 can do the work of class 2 . A whopping $4.6 \%$ and $0.9 \%$ of children in class 3 and 8 
respectively cannot read at all! (Uwezo, 2013: 8). There was also a general drop in comprehension levels. The number of children in class 4-5, for example, who cannot read and comprehend a class two level story increased to six out of ten in 2012 from five out of ten in 2011 (ibid: 15), seven out of 100 children in class 8 can neither read a simple story in English nor Kiswahili (ibid: 3). This further motivated the researcher to conduct the study in a boy's school and in a rehabilitation setting. Therefore, the current study sought to address the effect of modeling discipline management method on English language reading readiness of children in class one in Kericho Rehabilitation School.

\section{Objective of the Study}

The study sought to determine the effect of modeling discipline management on English Language Reading Readiness of children in class one at Kericho Rehabilitation School, Kenya.

\section{Hypothesis of the Study}

The study sought to establish that:

$\mathrm{H}_{\mathrm{O} 1}$ : There is no significant difference between the mean score of the group of children taught without using the modeling discipline management and mean score of the group of children taught using the modeling discipline management on English Language Reading Readiness of children in class one at Kericho Rehabilitation School.

\section{Significance of the Study}

The findings of this study may help the Ministry of Education (MOE) to formulate and implement classroom practices for class one learners in the rehabilitation schools. The findings of this study may be useful to the Kenya Institute of Curriculum Development (KICD), in coming up with appropriate and clear policies to guide learning in rehabilitation schools to enhance English Language Reading Readiness. Teachers may also use the findings to develop standardized classroom practices for rehabilitation schools. It is also believed that the data generated will constitute part of the knowledge pool from which future research can borrow and form a basis for further related research.

\section{Literature Review}

\section{Concept of English Language Reading Readiness}

According to UNICEF (2012) there are three segments of English Language Reading Readiness which consist of: Ready children (focusing on children's learning and development), Ready schools (focusing on the school environment along with practices that foster and support a smooth transition for children into primary school and advance and promote the learning of all children) and Ready families (focusing on parental and caregiver attitudes and involvement in their children's early learning and development and transition to school). All three segmentations are of significance and must work in tandem, because English language reading readiness is a period of transition that needs the interface between individuals, families and systems. The recent literature has a common theme that English language reading readiness is an 'encompassing' concept, which includes cognitive, socioemotional, and physical components (Janus \& Offord, 2007).

Research studies on the prevalence of speech and language impairments propose that approximately $7 \%$ of children in primary schools usually exhibit difficulties (Law, et al 1996). Increasingly it is recognized that children with identified language challenges have low academic performance in comparison to their peers in secondary and primary schools. (Stothard, et al 2001; Conti-Ramsden, Durkin, Simkin \& Knox, 2009). There are now distinct causal associations between a child's degree of language and communication development at school entry age and how this impacts on their literacy learning and resultant attainment (Catts, 2002; Catts \& Kamhi, 2005; Nathan, et al 2004). However, as with typical development, there is variation in how children with speech and language impairment progress. Lately, there has been a major concern on late development of language in early readers. Until relatively recently, concerns about the development of language were purely the responsibility of the parent and the early years practitioner (health visitors, early educators, speech and language therapists, psychologists and the like).

\section{Concept of Classroom Practices}

Classroom practices have been viewed largely as any steps taken by teachers to present the environment that supports and facilitates both academic and social-emotional learning (Evertson \& Weinstein, 2006). Rules and routines are powerful preventative elements to classroom organization and management plans because they create a behavioural context for the classroom that includes what is expected, what will be reinforced, and what will be re-taught if inappropriate behaviour occurs (Colvin, Kameenui \& Sugai, 1993). This prevents problem behavior by giving students particular, appropriate behaviours to engage in. Monitoring student behaviour permits the teacher to acknowledge students who are attaining in appropriate behaviour and eliminate misbehaviour from 
progressing (Colvin, Sugai \& Patching, 1993).

According to Evertson and Weinstein (2006), the main parts of classroom practices comprise of: (1) classroom organization resources; (2) teaching methodologies; (3) classroom assessment practices; (4) discipline management; (5) organizing and planning; (6) conducting instruction and maintaining momentum; and (7) getting the year off to a good start. For the purpose of this review, universal or whole-class classroom practices is described as a composition of instructional and non-instructional classroom procedures implemented by teachers in classroom settings with all students for the aim of teaching cognitive and pro-social behavior as well as preventing and minimizing inappropriate behaviour.

\section{Link between Classroom Practices and English Language Reading Readiness}

An effective management of a classroom is closely for prevention measures. Children's behaviour is moulded by environment's social context during the process of development (Kauffman, 2005). Most behavioural disorders start with orbecome bad through behavioural practices such as reinforcement, modeling, extinction, and punishment (Kauffman, 2005; Patterson, Reid, \& Dishion, 1992). The classroom set-up performs a major part in the emergence and persistence of behaviour aggression. Early intervention and appropriate treatment for students at-risk for Emotional and Behavioral Disorders (EBD) is crucial to eliminate further occurrences of fatal behaviours developing (Kauffman, 2005; Greer-Chase, Rhodes, \& Kellam, 2002). The progression and malleability of maladapted behaviour is mostly affected by teacher's classroom management practices in the very initial grades (Greer-Chase, Rhodes, \& Kellam 2002).

Research depicts that aggressiveness of students is determined by either aggressive nature or classroom disruptions environments which are most likely to be aggressive in later grades (Greer-Chase, Rhodes \& Kellam, 2002). English language reading readiness involves the quality of the school environment that has been associated with greater rates of student retention due to a well-diversified system of enhancing English language reading readiness (Lloyd, Mensch, Clark, 2000). Research studies have showed that much positive perceptions of classroom structure and overall school environment by children in class one have closely associated with high academic engagement due to high level of language readiness (Valeski \& Stipek 2001).

\section{Discipline Management and English Language Reading Readiness}

According to Burchinal, et al (2000), best-trained and supportive teachers, who apply reasonable degree of praise, proactive teaching strategies, and non-harsh discipline, can play an extremely significant role in fostering the social and emotional skills development and preventing the conduct problems in young children together with enhancing language readiness among children. They further assert that children from low-income households enrolled in high quality preschool settings are more willing to adapt too cognitively, socially, and emotionally, than their counterparts from children in low- income households situations. Other studies (Pianta \& Walsh, 1998; Werner, 1999) established that a supportive relationship with at least one teacher has been shown to be one of the most important protective factors influencing high-risk children's level of readiness. This is expected to influence the pupils English Language Reading Readiness in the area of study. Thus, effective discipline should be one that is applied with mutual respect in a firm, fair, reasonable and consistent way. This is supported by Demma (2010), who states that the goal is to protect the child from danger, help the child learn self-discipline, and develop a healthy conscience and an internal sense of responsibility and control. It should also instill values and makes the child ready for school. This will enhance pupils English Language Reading Readiness.

\section{The Modeling Method of Classroom Discipline Management}

Modelling or modeling is a method used in certain techniques of psychotherapy whereby the client learns by imitation alone, without any specific verbal direction by the therapist and a general process in which persons serve as models for others, exhibiting the behaviour to be imitated by the others. This process is most commonly discussed with respect to children in developmental psychology. Confusingly, the word refers both to the behaviour of the learner and the teacher. Modelling is an important component of classroom discipline programming, which field has further developed specialized techniques involving modelling. As the name implies, in the modeling the child learns new skills by imitating another person, such as a parent or teacher, who performs the behaviour to be acquired. A younger child may be exposed to behaviours or roles in peers who act as assistants to therapist and then be encouraged to imitate and practice the desired new responses. For example, modeling may be used to promote the learning of simple skills such as self-good grooming for a deviant child, or more complex skills such as being more effective in social situations such as respecting and obeying school and classroom rules and routine. To model positive classroom behaviour effectively using this theory, a teacher must exude realness, acceptance, trust and empathy. By being aware of the learners' feeling and communicating them successfully, a teacher will embody the behaviours that he/she wishes to see from their learners. 


\section{Methodology}

\section{Research Design}

The research design of a study describes the principal approach that researchers use to respond to their research questions (Polit \& Beck, 2010). The study adopted a case study research design because the study was done in one institution that utilized a quasi-experimental design where the phonics instructional method was the independent variable while the English Language Reading Readiness of the children was the dependent variable. For the purpose of this study, a one group pre-test post-test quasi-experimental design was used. This is because the subjects could not be randomly assigned to either the experimental or the control group and the researcher couldn't control which group would get the treatment. In other words, participants were not entitled to the same opportunity of being in the control or the experimental groups, or of receiving or not receiving the treatment (Best \& Kahn, 2003). In this study, there was only one selected group under observation, with a careful measurement being done before applying the experimental treatment and then measuring after.

\section{Target Population}

Kericho Rehabilitation School is the only school in Kenya that offers educational and rehabilitation programmes for boys in class one to three who are admitted to the school through a judicial process. Polit and Beck (2010) contend that quantitative researchers should select the largest sample possible so that it acts as a representative of the target population. Since the study was about children in standard one, the researcher used all the 25 children in class one. Additionally, all the four teachers and the head teacher were included in the study.

\section{Data Collection Instruments}

The researcher used a triangulation approach to collect data from the respondents. In this case, data collection was done using a combination of an English Language Reading Readiness Test, a questionnaire for head teacher and teachers, document analysis on the availability/non-availability of the various documents and records used by teachers and other school departments in class one and observation schedule for classroom teaching.

\section{Data Collection Procedures}

Before the start of data collection, the researcher obtained an introductory letter from University of Nairobi, School of Graduate Studies, authorizing implementation of the study. A permit from the National Commission of Science, Technology and Innovation (NACOSTI) and permission from the Department of Children's Services to carry out the study was also acquired. The researcher then proceeded to the rehabilitation school where he sought audience with the head teacher and Manager for reconnaissance. The teachers and the head teacher were issued with the questionnaires to respond. The researcher allowed the respondents sufficient time to accurately fill in the copies of the questionnaire with the required information after which the documents were collected for data extraction and analysis.

\section{The Findings}

The study sought to establish the effect of the phonics instructional method on English Language Reading Readiness of children in class one at Kericho Rehabilitation School through the following null hypothesis:

Ho1: $\quad$ There is no significant difference between the mean score of the group of children taught without using the modeling discipline management and mean score of the group of children taught using the modeling discipline management on English Language Reading Readiness of children in class one at Kericho Rehabilitation School.

\section{Children's Pre-test performance in English Language Reading Readiness test}

In the study, the pre-test was administered to the fourteen children in order to establish their level of performance in English Language Reading Readiness before administering the intervention. The individual children's mean scores for the pre-test results were obtained by marking the children's test out of 10 marks per every item. Table 2 presents the results of the children's marked scripts for the pre-test English Language Reading Readiness test.

Table 1: Pre-test Mean Scores of children

\begin{tabular}{lllllllllllllll}
\hline Class one children & 1 & 2 & 3 & 4 & 5 & 6 & 7 & 8 & 9 & 10 & 11 & 12 & 13 & 14 \\
\hline Score & 18 & 20 & 18 & 18 & 16 & 12 & 09 & 12 & 08 & 06 & 08 & 06 & 04 & 00 \\
Percentage & 36 & 40 & 36 & 36 & 32 & 24 & 18 & 24 & 16 & 12 & 16 & 12 & 08 & 00 \\
\hline
\end{tabular}

Overall mean score $=11.071(22.14 \%)$

Source: Researcher

Table 1 shows a total of 14 children took part in an English Language Reading Readiness pre-test. The test consisted of 10 short answer structured questions with a maximum score of 50 marks. The questions were based on the different aspects of the class one English syllabus. The English Language Reading Readiness Test items were based on; set scores in letter sounds, spelling, reading and writing simple English words. The highest pre- 
test score was 20 (40\%), scored by one child, three children scored $18(36 \%)$ while the lowest score of $0(0 \%)$ was scored by one child. All the children scored below the half mark $25(50 \%)$. This is an indication that almost all the children had low pre-test scores. The overall mean score in the English Language Reading Readiness pre-test was $11.071(22.14 \%)$.

The low performance in the English Language Reading Readiness test by the class one children was due to the fact that they were evaluated before the modeling discipline management method was applied. The children did not see the need to model their conduct and behavior to any of the role models within their school environment because they seemed to see none of it. The teachers were always harsh and kept on reminding them of their bad behaviours that made parents take them to the rehabilitation school. During the English Language Reading Readiness test, the children associated the usually harsh and abusive learning atmosphere with the test management. For this purpose effective teachers create conditions of cooperation, discipline and responsibility both for themselves and for their students (Riaz, 2009). Managing a classroom is the ultimate responsibility of a teacher.

A t-test of the mean of pretest and post test was done. The results of the unigroup independent sample t-Test are indicated on Table 3.

Table 2: Independent Sample t-Test on pre-test scores

\begin{tabular}{lccccc}
\hline & Mean & Std. Error Mean & T & DF & Sig. (2-tailed) \\
\hline Equal variances assumed & .458 & .188 & 2.27 & 13 & .32 \\
\hline
\end{tabular}

Source: Researcher

Table 2 contains the t-test on the pre-test scores. The T value of 2.27 with a degree of freedom of 13 and a 2 tailed significance of 0.32 means that we accept the null hypothesis that there was no significant difference between the mean score of the group of children taught without using the modeling discipline management method and the mean score of the group taught using the modeling discipline management method in English Language Reading Readiness of children in class one at Kericho Rehabilitation School.

\section{The Intervention - the Modelling Approach to Classroom Discipline Management}

Before the teachers were trained on the Modelling method of classroom discipline management, the researcher observed that the teachers went to class with an attitude - that of the assumption that the children were criminals and so the main concern was to correct their bad behaviours among the learners. The researcher had noted that when a teacher entered class, there was a complete lull among the children, an indication of fear. The teacher then gave the commanding instructions and the children appeared not to care much. The teacher kept reminding the children of "what will happen to them if they did not follow instruction (not completing the assignment and submitting their books for marking on time)". Some children would even complete the statement for the teacher "Ni kiboko" - meaning, "it's corporal punishment". The researcher observed that corporal punishment and verbal abuses were quite rampant since the children were perceived to be wrong doers who were committed to rehabilitation school for behavior modification. The researcher observed that five children just never cared and would be seen leaning on their desks in a sleeping manner, an indication that they had just switched off. The teacher would be seen quarelling them openly. The researcher introduced the modeling discipline management method as postulated by Jones (2015). According to Jones, to build positive classroom discipline, teachers should model appropriate behaviour, and use appropriate classroom management methods. Likewise, when teachers act maturely and competently, learners will see them as role models after whom they pattern their own behavior. Modelling the behaviour that teachers want in the learners involves teachers exhibiting respectfulness, trust, enthusiasm, interest, love, care, and courtesy in their everyday dealings with learners, for the learners will return the favours in kind.

After the six weeks of the application of the modeling method of classroom discipline management, the researcher observed a big change in the behavior of children, especially during the English lesson. The teacher was more friendly, loving and caring. The teacher respected the children's opinion and even corrected their wrong responses with humaneness. All children were more willing to go near the teacher (a situation that was hitherto not possible). The five children who seemed to have switched off from making any initiative in class were a complete opposite of themselves. They were very active in making attempts to read, write, spell and present their exercise books to the teacher for marking. The modeling method was also supported by the B. F. Skinner model of discipline management. The Skinnerian model emphasizes that behavior that is rewarded tends to be repeated, while behavior that receives no reward tends to be abolished. In order to control discipline, Skinner's model rewards good behavior and punishes bad behavior. Skinner focused his approach on reinforcement. To model positive classroom behaviour effectively using this theory, a teacher must exude realness, acceptance, trust and empathy. By being aware of the learners' feeling and communicating them successfully, a teacher will embody the behaviours that he/she wishes to see from their learners.

According to Burchinal, Roberts, Hooper and Zeisel (2000), best-trained and supportive teachers, who apply reasonable degree of praise, proactive teaching strategies, and non-harsh discipline, can play an extremely significant role in fostering the social and emotional skills development and preventing the conduct problems in 
young children together with enhancing language readiness among children. This is supported by Demma (2010), who states that the goal is to protect the child from danger, help the child learn self-discipline, and develop a healthy conscience and an internal sense of responsibility and control. It should also instill values and makes the child ready for school. This will enhance pupils English Language Reading Readiness.

This study administered a post-test to fourteen class one children after their teachers had been trained and applied the modeling discipline management approach. Table 3 presents the pre-test and post-test mean score.

Table 3: Pre-test and Post-test Mean Scores

\begin{tabular}{lccccc}
\hline Class one children & Pre test score & $\%$ & Post Test score & $\%$ & Post test (\%) gain \\
\hline 1 & 18 & 36 & 44 & 88 & 52 \\
2 & 20 & 40 & 48 & 96 & 56 \\
3 & 18 & 36 & 36 & 72 & 36 \\
4 & 18 & 36 & 42 & 84 & 48 \\
5 & 16 & 32 & 36 & 72 & 40 \\
6 & 12 & 24 & 36 & 72 & 48 \\
7 & 09 & 18 & 28 & 56 & 38 \\
8 & 12 & 24 & 34 & 68 & 44 \\
9 & 08 & 16 & 26 & 52 & 36 \\
10 & 06 & 12 & 28 & 56 & 44 \\
11 & 08 & 16 & 28 & 56 & 40 \\
12 & 06 & 12 & 22 & 44 & 32 \\
13 & 04 & 08 & 22 & 44 & 36 \\
14 & 00 & 00 & 08 & 16 & 16 \\
\hline
\end{tabular}

Overall mean: Pre-test=11.071 (22.142\%) $\quad$ Post-test=31.285 (62.571\%)

Source: Researcher

Table 3 shows the pre-test and the post-test mean scores for each child in English Language Reading Readiness test. The highest post-test score is indicated as $48(96 \%)$ as compared to the highest pre-test score of 20 $(40 \%)$. The lowest post-test score was $8(16 \%)$ as compared to the lowest pre-test score of $0(0 \%)$. The results in table 3 shows that no child scored a score higher than $50 \%$ in the pre-test as compared to post-test where 11 children out of the 14 got a score more than $50 \%$.

These results on Table 3 are indications that the students performed better in the post-test English Language Reading Readiness test than in the pre-test. The results obtained indicate that using phonics can help the learners learn to read and form words effectively. Furthermore students' word recognition significantly improved. It seems that using modeling as an approach for classroom discipline management relieves the children much of the anticipated harsh corrective measures meted on the children. The children appeared more relaxed since the teachers seemed to care and showed them a lot of love. The findings from the questionnaire on modeling discipline management was presented in table 4

Table 4 Modeling Classroom discipline management

\begin{tabular}{|c|c|c|c|c|c|}
\hline Classroom discipline management & $\mathbf{N}$ & Minimum & Maximum & Mean & $\begin{array}{l}\text { Std. } \\
\text { Deviation }\end{array}$ \\
\hline I am a member of the school discipline committee & 4 & 1 & 1 & 1.00 & .000 \\
\hline $\begin{array}{l}\text { The children exhibit different behaviours during English } \\
\text { language reading lessons }\end{array}$ & 4 & 5 & 5 & 5.00 & .000 \\
\hline $\begin{array}{l}\text { The children seem to be lacking positive behavior models } \\
\text { wherever they come from }\end{array}$ & 4 & 4 & 4 & 4.00 & .000 \\
\hline $\begin{array}{l}\text { The use of praise and rewards reinforces desirable behaviours } \\
\text { during English reading lesson }\end{array}$ & 4 & 5 & 5 & 5.00 & .000 \\
\hline $\begin{array}{l}\text { Respect and empathy to all learners in class motivates } \\
\text { classroom participation }\end{array}$ & 4 & 1 & 2 & 1.25 & .500 \\
\hline $\begin{array}{l}\text { Modelling method has a long lasting impact on learner } \\
\text { discipline in class }\end{array}$ & 4 & 2 & 4 & 2.50 & 1.000 \\
\hline I can only report wrong-doers to the Head teacher/Manager & 4 & 4 & 5 & 4.25 & .500 \\
\hline $\begin{array}{l}\text { I punish learners who don't perform well in English language } \\
\text { reading examinations }\end{array}$ & 4 & 5 & 5 & 5.00 & .000 \\
\hline $\begin{array}{l}\text { I encourage the use of modeling as a method of managing } \\
\text { learner discipline during English lessons }\end{array}$ & 4 & 2 & 2 & 2.00 & .000 \\
\hline
\end{tabular}

Source: Researcher

The findings in Table 4 indicated that teachers agreed they were members of the school discipline committee as shown by a mean of 1.00 and a standard deviation of 0.00 . According to Yaroson (2004), school authorities could also cause disciplinary problems through organisational lapses manifesting in inappropriate policies and 
programmes. For instance, the nature of the school curriculum, the size of classrooms, availability of teaching and learning resources, the competency of teachers handling classrooms, and the nature of time-table schedules are all factors that determine school discipline.

The teachers strongly agreed that children exhibit different behaviours during English language reading lessons as shown by a mean of 5.00 and a standard deviation of 0.00 . Gyamera (2005) noted that ignorance of rules, lack of cooperation from learners; frustration and peer pressure have a causative effect on the general learners' behaviour.

Teachers agreed that children seem to be lacking positive behavior models wherever they come from as shown by a mean of 4.00 and a standard deviation of 0.00 . Discipline in the classroom is a prerequisite if any meaningful learning is to take place and that no meaningful learning can take place in a chaotic environment (Lewis, 1999). Lewis further observes that of all the activities that comprise the role of the teacher, classroom discipline is one of the most significant. The teacheres role is made more problematic when classrooms and schools become unmanageable. "Teachers may waste special teaching time trying to settle disciplinary problems." (Lewis, 1999; 19).

Teachers agreed that the use of praise and rewards reinforces desirable behaviours during English reading lesson as shown by a mean of 4.00 and a standard deviation of 0.00 . Mbiti (2007) asserts that the school administrators should provide leadership and direction in order to maintain school discipline. Further, Mbiti (2007) identifies the following as the key roles of the school head: maintaining discipline; providing guidance and counseling to students; accounting for the students; managing curriculum administration; and identifying student ${ }^{\mathrm{ee}} \mathrm{s}$ individual problems and solving them.

Teachers agreed that respect and empathy to all learners in class motivates classroom participation as shown by a mean of 1.25 and a standard deviation of 0.50. Amado and Freire (2009) points out that the first level of indiscipline are those incidents of disruptive nature whose disturbance affects the good classroom functioning. The incidents that might be framed in the second and third levels, are conflicts among peers and conflicts within teacher-student relationship, which might be taken on proportions of violence and even delinquency, the latter presents a minor frequency than the former (Amado, 2005).

The teachers agreed that modelling method has a long lasting impact on learner discipline in class as shown by a mean of 2.50 and a standard deviation of 1.00 . To improve the behavior of misbehaving learners, there are many educational programs on the market. Researchers Brophy and Luke (Gaustad, 1992), found that rewards and punishments based on the behavior of individuals in a group are effective in remediating misbehavior.

The teachers disagreed that they could only report wrong-doers to the Head teacher/Manager as shown by a mean of 4.25 and a standard deviation of 0.500 . According to Mbiti (2007) the head of the school is responsible for the overall running of the school and maintenance of discipline. He is required to support teachers in curriculum implementation and maintenance of discipline.

The teachers strongly disagreed that they punished learners who don't perform well in English language reading examinations as shown by a mean of 5.00 and a standard deviation of 0.00 . A child's exposure to a responsive and expansive language environment, in the context of warm, positive relationships with parents and teachers sets the stage for positive language learning, a key indicator of academic readiness (Cappelloni, 2011).

The teachers however agreed that they encourage the use of modeling as a method of managing learner discipline during English lessons as shown by a mean of 2.00 and a standard deviation of 0.00 . In order to promote good behaviour, the school head should state school rules in clear and simple terms (Wachanga, 2003). It is the teachers duty to maintain discipline in class and maintain orderliness (Wachanga, 2003). The head of department is the overall in charge of the guidance and counseling department, he/she has the responsibility to make it certain that the department is able to fulfill its mandate (Muloki \& Edwin, 2009).

Table 5: One-Sample Statistics of modeling classroom discipline management

\begin{tabular}{lllll}
\hline & $\mathrm{N}$ & Mean & Std. Deviation & Std. Error Mean \\
\hline $\mathrm{x} 4$ & 4 & 17.813 & 1.197 & .598 \\
\hline
\end{tabular}

One-Sample Test

\begin{tabular}{llllll} 
Test Value $=31.29$ & & & & \\
\hline $\mathrm{T}$ & $\begin{array}{l}\text { Degree } \\
\text { Freedom }\end{array}$ & of Sig. (2-tailed) & Mean Difference & $\begin{array}{l}\text { 95\% Confidence } \\
\text { Difference }\end{array}$ & Interval of the \\
\cline { 3 - 6 } & & & Lower & Upper \\
\hline-22.523 & 3 & .000 & -13.478 & -15.382 & -11.573 \\
\hline
\end{tabular}

$\mathrm{x} 4 \quad-22.523 \quad 3$
The results given $(\mathrm{df}=3, \mathrm{p}<0.05)$

Source: Researcher

The significant value 0.000 is less than the p-value $0.05 .0 .000>0.05$, we therefore reject the null hypothesis and conclude that there is high significant relationship between the means. Therefore classroom discipline management has direct and greater impact on the final student results in English Language readiness in English 
Language. Therefore such classroom discipline (corporal punishment, manual work and verbal abuse) among teachers with students should be adhered to for a better cohesive learning and improvement of classroom practices in Kericho Rehabilitation School and other similar institutions.

\section{Conclusion and Recommendation}

The study notes that Rehabilitation Schools in Kenya are offering the education service as well as offer the corrective programmes to children whom the judicial process places them in the institutions. The study recommends that the Department of Children Services should establish an ECDE Centre in order to lay a foundation for the learning of children within the rehabilitation schools. The Department should hire ECDE teachers to help children in class one who still require ECD services. The further notes that the Quality Assurance Department of the Ministry of Education should focus more on the quality of education offered in Rehabilitation Schools. It's also recommended that the teaching of English should emphasize the integration of the modeling discipline management approach in the foundation of pre-reading skills among the learners of class one in rehabilitation schools. Lastly, it's highly recommended that further research on the teaching and learning of children in rehabilitation schools be conducted to establish if the service is beneficial to the learners in all the rehabilitation schools in Kenya

\section{References}

Best, J. W., \& Kahn, J. V. (2003). Research in education (9th ed.). Boston: Allyn and Bacon.

Beard,R. (1987). Developing Reading 3-13. London: Hodder and Stoughton.

Catts, H.W. \&Kamhi, A.G., (2005). Language and Reading Disabilities. Boston: Allyn\& Bacon.

Catts, H.W., Fey, M.E., Tomblin, J.B. (2002). A Longitudinal Investigation of Reading Outcomes in Children With Language Impairment. Journal of Speech, Language, and Hearing Research, 45 1142-1157.

Dubeck, M, Jukes, M. \& Okello , G. (2012). Early Primary Literacy Instruction in Kenya. In Comparative Education Review, Vol. 56, No.!. February 2012.

Durkin,0. (1983). Children who read earlY. New York: Teachers College Press.

Heilman, A.W. Blair, T.R \& Rupley, W.H. (1981). Principles and practices oj teaching. (5th ed.) Columbus. Ohio: Charles E. Merril

Janus, M. \&Offord, D. R. (2007) Development and psychometric properties of the Early Development Instrument (EDI): A measure of children's language readiness. Canadian Journal of Behavioural Science, 39, 2, 71-75

Kinyua, P. M. (2014). Exploring Giftedness among Learners with Juvenile Delinquency in Selected Rehabilitation Schools in Kenya (Doctoral dissertation, Kenyatta University).

Law,J., Boyle, J., Harris, F., Harkness, A., \& Nye, C. (2000b). The feasibility of universal screening for primary speech and language delay: A systematic review of the literature. Developmental Medicine and Child Neurology. 42, 190-200

Law,J., Boyle, J., Harris, F., Harkness, A., \& Nye, C. (2000a). The relationship between the natural history and prevalence of primary speech and language delays: Findings from a systematic review of the literature. International Journal of Language and Communication Disorders. 35, 2,165-188.

Maneno, R.,]. (2008). Identification Processes oj .Articulatio» and Phonemic Disorders in Children with Communication Disorders in primary Schools. Nairobi Province Kenya. A Ph.D Thesis at Kenyatta University.

Mugenda, O. M. and Mugenda, A. G. (2003) Research Methods: Acts Press, Nairobi.

Stothard, S.E., Snowling, M.J., Bishop, D.V.M., Chipchase, B.B. and Kaplan, C.A., 1998, Language-impaired preschoolers: A follow-up into adolescence, Journal of Speech and Hearing Research, 41: 407-418

UNICEF.(2012). Language readiness.A Conceptual Framework. New York: United Nations Children's Fund. Retrievedfrom: http://www.unicef.org/education/files/Chil2Child_ConceptualFramework_FINAL(1).pdf on $12^{\text {th }}$ November, 2017

Uwezo.(2013). Monitoring Learner Achievement Report. fromhttp://www.uwezo.net/wp.content/uploads/2009/13/ke - 2013 on 16th December 2015. 